\title{
PENGARUH KEPUASAN KERJA, KOMITMEN ORGANISASIONAL DAN MOTIVASI KERJA TERHADAP INTENSI TURNOVER KARYAWAN PT. XYZ
}

\author{
Rizqa Amalia ${ }^{1}$ \\ Anik Herminingsih ${ }^{2}$ \\ amaliarizqaa@gmail.com ${ }^{1}$ \\ aherminingsih@gmail.com ${ }^{2}$
}

Magister Managemen Universitas Mercu Buana

Diterima: Mei 2020, Disetujui: Juni 2020, Dipublikasikan: Juli 2020

\begin{abstract}
Continuous and increasing turnover is the beginning of a phenomenon in a company. PT. Hero Supermarket, Tbk currently has a high turnover rate. This is based on the data of the last three years, the number of employees who have dropped out of their presentations has increased from 2015 to 2017. This study aims to determine the effect of job satisfaction, organizational commitment and work motivation on turnover intentions. The research was conducted at PT. Hero Supermarket, Tbk with a sample of 37 respondents. This research method uses quantitative methods, data analysis with multiple linear regression. The results of this study state that job satisfaction, organizational commitment and work motivation together have a significant effect on turnover intention. While work motivation does not partially have a significant effect on turnover intentions.
\end{abstract}

Keyword : Job Satisfaction, Organizational Commitment, Work Motivation, Turnover Intentions

\begin{abstract}
ABSTRAK
Terjadinya turnover yang terus menerus dan mengalami peningkatan menjadi awal timbulnya fenomena didalam suatu perusahaan. PT. Hero Supermarket, Tbk saat ini memiliki angka turnover yang tinggi. Hal ini berdasarkan data tiga tahun terakhir jumlah karyawan yang keluar presentasenya mengalami peningkatan dari tahun 2015 sampai dengan 2017. Penelitian ini bertujuan untuk mengetahui pengaruh kepuasan kerja, komitmen organisasional dan motivasi kerja terhadap intensi turnover. Penelitian dilakukan di PT. Hero Supermarket, Tbk dengan sampel sebanyak 37 responden. Metode penelitian ini menggunakan metode kuantitatif, analisa data dengan regresi linear berganda. Hasil penelitian ini menyatakan bahwa kepuasan kerja, komitmen organisasional dan motivasi kerja secara bersama-sama berpengaruh signifikan terhadap intensi turnover. Sedangkan motivasi kerja tidak berpengaruh signifikan secara parsial terhadap intensi turnover.

Kata Kunci : Kepuasan Kerja, Komitmen Organisasional, Motivasi Kerja, Intensi Turnover
\end{abstract}

\section{PENDAHULUAN}

\section{Latar Belakang}

Turnover merupakan salah satu dinamika yang terjadi di lingkungan kerja. Tingginya angka turnover harus disikapi serius oleh perusahaan karena akan mengganggu proses kegiatan SDM di perusahaan. Peningkatan angka turnover yang terus tinggi mengakibatkan adanya intensi turnover. PT. XYZ merupakan salah satu pelopor ritel modern, saat ini memiliki angka turnover yang tinggi. Hal ini dibuktikan dengan melihat data turnover karyawan selama tahun 2015 sampai dengan 2017 dengan 
presentase secara berturut-turut sebesar 10,9\%; 11,5\% dan 11,8\%. Tingginya faktor jumlah karyawan keluar menjadi perhatian penting manajemen dengan melihat kepuasan kerja dan motivasi kerja para karyawannya.

\section{Rumusan Masalah}

1. Apakah kepuasan kerja berpengaruh terhadap intensi turnover karyawan PT. Hero Supermarket, Tbk?

2. Apakah komitmen organisasional berpengaruh terhadap intensi turnover karyawan PT. Hero Supermarket, Tbk ?

3. Apakah motivasi kerja berpengaruh terhadap intensi turnover karyawan PT. Hero Supermarket, Tbk?

\section{TINJAUAN PUSTAKA}

\section{Intensi Turnover}

Mathis \& Jackson (2001) menyatakan bahwa intensi turnover adalah proses dimana tenaga kerja meninggalkan organisasi dan harus ada yang menggantikannya. Intensi turnover dapat dikatakan sebagai keinginan individu untuk keluar dan berpindah mencari alternatif pekerjaan lain yang lebih baik. Menurut Mathis and Jackson (2004), turnover dikelompokkan dalam turnover secara tidak sukarela dan turnover secara suka rela. Faktor penyebab turnover menurut Michael dalam Wahyuni et al. (2014) adalah: gaji/ upah, desain pekerjaan, pelatihan dan pengembangan, perkembangan karir, komitmen, kurangnya kekompakan dalam kelompok/ organisasi, ketidakpuasan dan bermasalah dengan atasan atau pengawas, rekrutmen, seleksi dan promosi . Mobley et al. dalam Firdaus (2017) menyatakan bahwa ada tahapan kognitif yang dialami karyawan sebelum meninggalkan pekerjaannya, yaitu:

1. Thoughts of quitting: Pemikiran karyawan untuk berhenti bekerja

2. Intention to search for another job: Suatu sikap karyawan yang berniat untuk mencari pekerjaan diperusahaan lain.

3. Intention to quit: Sikap seorang karyawan yang ini atau berniat keluar dari pekerjaannya saat ini dengan menunjukkan indikasi akan keluar atau berhenti bekerja. 


\section{Kepuasan Kerja}

Berdasarkan pendapat Luthans dalam Soegandhi et al. (2013), kepuasan kerja merupakan hasil dari persepsi karyawan mengenai seberapa baik pekerjaan mereka memberikan hal yang dinilai penting. Menurut Martoyo (1994) kepuasan kerja pada dasarnya merupakan keadaan emosional karyawan di mana terjadi ataupun tidak terjadi titik temu antara nilai balas jasa kerja karyawan dari perusahaan / organisasi dengan tingkat nilai balas jasa yang menang diinginkan oleh karyawan yang bersangkutan. Menurut Smith, Kendall \& Hulin dalam Soegandhi et al. (2013) ada beberapa dimensi kepuasan kerja yang dapat digunakan untuk mengungkapkan karakteristik penting mengenai pekerjaan, dimana orang dapat meresponnya. Dimensi tersebut adalah:

1. Pekerjaan itu sendiri (Work It self); Setiap pekerjaan memerlukan suatu keterampilan tertentu sesuai dengan bidang nya masing-masing. Sukar tidaknya suatu pekerjaan serta perasaan seseorang bahwa keahliannya dibutuhkan dalam melakukan pekerjaan tersebut, akan meningkatkan atau mengurangi kepuasan kerja.

2. Atasan (Supervision); Atasan yang baik berarti mau menghargai pekerjaan bawahannya. Bagi bawahan, atasan bisa dianggap sebagai figur ayah/ibu/teman dan sekaligus atasannya.

3. Teman sekerja (Workers); Merupakan faktor yang berhubungan dengan hubungan antara pegawai dengan atasannya dan dengan pegawai lain, baik yang sama maupun yang berbeda jenis pekerjaannya.

4. Promosi (Promotion); Merupakan faktor yang berhubungan dengan ada tidaknya kesempatan untuk memperoleh peningkatan karir selama bekerja.

5. Gaji/Upah (Pay); Merupakan faktor pemenuhan kebutuhan hidup pegawai yang dianggap layak atau tidak.

\section{Komitmen Organisasional}

Luthans (2011) mengemukakan bahwa komitmen organisasional adalah keinginan kuat untuk tetap sebagai anggota organisasi tertentu., keinginan untuk berusaha keras sesuai dengan keinginan organisasi dan keyakinan tertentu juga penerimaan nilai dan tujuan organisasi. 
Mathis \& Jackson dalam Nurandini (2014) komitmen organisasional adalah tingkat sampai dimana karyawan yakin dan menerima tujuan organisasional serta berkeinginan untuk tinggal bersama organisasi. Luthans (2011) menyebutkan terdapat dimensi dalam komitmen organisasional, yaitu :

1. Komitmen afektif (affective commitment); Komitmen afektif adalah keterikatan emosional karyawan, identifikasi, dan keterlibatan dalam organisasi.

2. Komitmen kelanjutan (continuance commitment); Komitmen kelanjutan adalah komitmen berdasarkan kerugian yang berhubungan dengan keluarnya karyawan dari organisasi.

3. Komitmen normatif (normative commitment); Komitmen normatif adalah perasaan wajib untuk tetap berada dalam organisasi karena memang harus begitu, tindakan tersebut merupakan hal benar yang harus dilakukan.

\section{Motivasi Kerja}

Robbins (2008) menyatakan bahwa motivasi adalah keinginan untuk melakukan sesuatu sebagai kesediaan untuk mengeluarkan tingkat upaya yang tinggi untuk tujuan-tujuan organisasi, yang di kondisikan oleh kemampuan upaya itu untuk memenuhi sesuatu kebutuhan individual. Sedangkan menurut Putrianti et al. (2014) motivasi merupakan faktor psikologis yang menunjukkan minat individu terhadap pekerjaan, rasa puas dan ikut bertanggung jawab terhadap segala kegiatan atau pekerjaan yang dilakukannya. Teori kebutuhan McClelland (McClelland's theory of needs) dikembangkan oleh David McClelland dan rekan-rekannya (Robbins, 2008). Teori tersebut berfokus pada tiga kebutuhan yaitu pencapaian, kekuatan, dan hubungan yang didefinisikan sebagai berikut:

1. Kebutuhan pencapaian (need for achievement), Kebutuhan yang menimbulkan dorongan untuk melebihi, mencapai target, berusaha keras untuk berhasil.

2. Kebutuhan kekuasaan (need for power), Kebutuhan untuk membuat individu lain berperilaku sedemikdian rupa sehingga mereka tidak akan berperilaku sebaliknya.

3. Kebutuhan afiliasi (need for affiliation), Keinginan untuk menjalin suatu hubungan antarpersonal yang ramah dan akrab. 


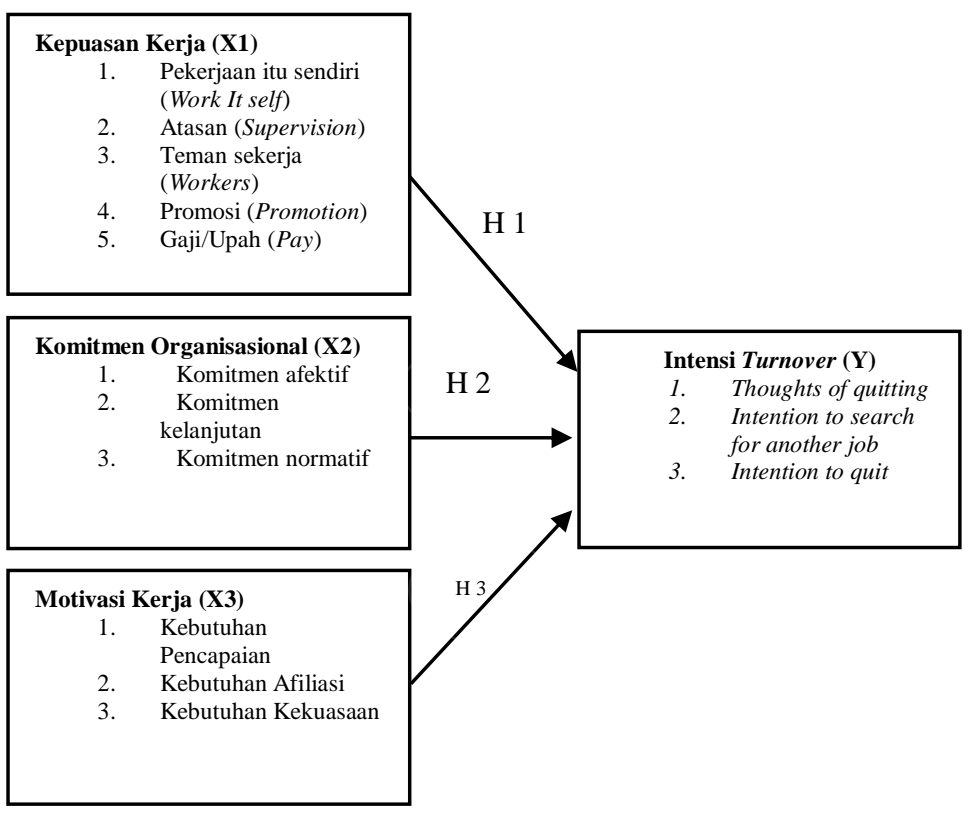

\section{Gambar 1. Kerangka Pemikiran}

Hipotesis - Berdasarkan rumusan permasalahan, hipotesis yang dikemukakan adalah sebagai berikut:

H1 : Kepuasan kerja berpengaruh terhadap intensi turnover.

$\mathrm{H} 2$ : Komitmen organisasional berpengaruh terhadap intensi turnover.

H3 : Motivasi kerja berpengaruh terhadap intensi turnover.

\section{METODE PENELITIAN}

Jenis penelitian yang digunakan dalam penelitian ini adalah penelitian kuantitatif dengan populasi penelitian adalah seluruh karyawan divisi HR di PT. XYZ yang berjumlah 37 orang dan sampel menggunakan sampel jenuh 37 orang. Teknik analisa data menggunakan analisis regresi linier berganda yang terdiri dari tes validitas, tes reliabilitas dan asumsi klasik. Uji hipotesis dilakukan dengan uji $\mathrm{F}$, uji t, uji koefisien determinasi dan korelasi antar dimensi. Data diolah dengan menggunakan software SPSS (Statistical Package for the social Sciences) versi 25.0. 


\section{HASIL DAN PEMBAHASAN}

\section{Hasil penelitian}

Karakteristik responden berdasarkan jenis kelamin yang paling banyak adalah perempuan dengan total 21 orang, usia paling banyak dengan kriteria 31 tahun - 40 tahun berjumlah 13 orang dan latar belakang pendidikan paling banyak jumlahnya dengan pendidikan sarjana (S1) berjumlah 30 orang.

\section{Uji Validitas}

Uji validitas merupakan instrument yang dihitung untuk mengetahui validitas alat ukur pada setiap variabel penelitian. Hasil uji validitas dari setiap indikator yang terdiri dari 44 pernyataan diwakili oleh nilai rata-rata masing-masing dimensi untuk setiap variabel yang diujikan menggunakan teknik Pearson Correlation melalui metode corrected item total correlation. Hasil uji dinyatakan valid apabila nilai $\mathrm{r}$ hitung lebih besar dari 0,349. Hasil penelitian ini menyatakan bahwa pada variabel komitmen organisasional, motivasi kerja dan intensi turnover seluruhnya dinyatakan valid, sedangkan variabel kepuasan kerja ada dua indikator yang dinyatakan tidak valid.

\section{Uji Reliabilitas}

Instrumen yang reliabel adalah instrumen yang bila digunakan beberapa kali untuk mengukur obyek yang sama, akan menghasilkan data yang sama. Pengujian data dilakukan dengan uji konsistensi internal dan menggunakan koefisien Cronbach's Alpha. Untuk instrumen berupa kuesioner, indeks reliabilitas dinyatakan reliabel jika $r$ alpha yang diperoleh memiliki nilai lebih dari 0,6. Hasil uji reliabilitas untuk variabel dalam penelitian ini seluruhnya dinyatakan reliabel dengan nilai Cronbach's Alpha lebih dari 0,60 .

\section{Uji Normalitas Data}

Uji normalitas bertujuan untuk menguji apakah dalam model regresi, variabel terikat dan variabel bebas keduanya mempunyai distribusi normal atau tidak. Hasil uji normalitas menunjukkan penyebaran residual yang normal mengikuti dan menyebar di sekitar garis diagonal.

\section{Uji Multikolinearitas}

Uji multikolinearitas bertujuan untuk menguji apakah model regresi ditemukan adanya korelasi antar variabel bebas (independen). Pengujian ini dapat menggunakan uji 
VIF (variance inflation factor). Suatu model bebas regresi dikatakan bebas dari multikolinearitas apabila Nilai tolerance $>0,10$ dan nilai $\mathrm{VIF}<10$ maka tidak terjadi multikolinearitas. Hasil uji multikolinearitas pada penelitian ini menunjukkan bahwa seluruh variabel memiliki nilai toleransi diatas 0,10 dan nilai VIF dibawah 10 , sehingga dapat dinyatakan bahwa model regresi tidak terjadi multikolinearitas.

\section{Uji Heteroskedastisitas}

Uji heteroskedastisitas bertujuan untuk menguji apakah dalam model regresi terjadi ketidaksamaan variance dari residual suatu pengamatan ke pengamatan lain, maka disebut homoskedastisitas dan jika berbeda disebut heteroskedastisitas. hasil dari uji heteroskedastisitas yang menunjukan adanya titik-titik yang menyebar atau berada di sekitar angka 0 . Penyebaran titik-titik tersebut tidak membentuk pola tertentu, sehingga dapat dikatakan bahwa data bersifat homogen atau tidak terjadi gejala heteroskedastisitas.

Analisis Regresi Linier Berganda - Analisis regresi linier adalah analisis yang digunakan untuk mengukur besarnya pengaruh antara dua atau lebih varibael independen terhadap satu variabel dependen dan memprediksi variabel dependen dengan menggunakan variabel independen. Hasil analisis regresi linier berganda sebagai berikut:

\section{Analisis Regresi Linier Berganda}

\section{$Y=(6,378)-0,370 \times 1-0,565 \times 2-0,190 \times 3$}

1. Hasil perhitungan menunjukkan bahwa nilai a (konstanta) adalah 6,378. Hal ini dapat diartikan jika Kepuasan Kerja (X1), Komitmen Organisasional (X2) dan Motivasi Kerja (X3) bernilai sama dengan nol, maka Intensi Turnover bernilai 6,378. Konstanta tersebut merupakan variabel yang nilai datanya bersifat tetap dan tidak bisa diubah.

2. Nilai koefisien regresi variabel Kepuasan Kerja (X1) bernilai negatif, yaitu (-0,370). Hal ini dapat diartikan bahwa terjadi hubungan negatif antara Kepuasan Kerja dengan Intensi Turnover. Jika nilai variabel Komitmen Organisasional (X2) dan Motivasi Kerja (X3) memiliki nilai tetap, maka variabel Intensi Turnover (Y) akan meningkat sebesar 0,370 atau $37 \%$. 
3. Nilai koefisien regresi variabel Komitmen Organisasional $\left(\mathrm{X}_{2}\right)$ bernilai negatif, yaitu (0,565) hal ini dapat diartikan bahwa terjadi hubungan negatif antara Komitmen Organisasional dengan Intensi Turnover. Jika nilai variabel Kepuasan Kerja (X1) dan Motivasi Kerja (X3) memiliki nilai tetap, maka variabel Intensi Turnover (Y) akan meningkat sebesar 0,565 atau $56,5 \%$.

4. Nilai koefisien regresi variabel Motivasi Kerja (X3) bernilai negatif, yaitu $(-0,190)$. Hal ini dapat diartikan bahwa terjadi hubungan negatif antara Motivasi Kerja dengan Intensi Turnover. Jika nilai variabel Kepuasan Kerja (X1) dan Komitmen Organisasional (X2) memiliki nilai tetap, maka variabel Intensi Turnover (Y) akan meningkat sebesar 0,190 atau $19 \%$.

\section{Uji F}

Hasil uji F menunjukkan nilai sebesar 55,036 dengan nilai signifikan sebesar 0,000. Nilai signifikan sebesar 0,000 atau lebih kecil dari 0,05 menunjukkan bahwa model regresi yang digunakan pada penelitian ini adalah signifikan.

\section{Uji t}

Pada uji t kriteria pengambilan keputusannya adalah bila nilai t hitung lebih besar dari t tabel atau nilai sig t hitung lebih kecil dari 0,05 maka dapat dinyatakan bahwa variabel independen memiliki pengaruh yang signifikan. Variabel Kepuasan Kerja memiliki nilai signifikansi 0,000 . Hal ini menunjukkan bahwa kepuasan kerja berpengaruh signifikan terhadap intensi turnover. Adapun besar pengaruh variabel kepuasan kerja adalah sebesar 0,370 atau 37\%. Variabel Komitmen Organisasional memiliki nilai signifikansi 0,000. Hal ini menunjukkan bahwa komitmen organisasional berpengaruh signifikan terhadap intensi turnover. Adapun besar pengaruh variabel komitmen organisasional adalah sebesar 0,565 atau 56,5\%. Variabel Motivasi Kerja memiliki nilai signifikansi 0,130 . Hal ini menunjukkan bahwa motivasi kerja tidak berpengaruh signifikan terhadap intensi turnover.

\section{Koefisien Determinasi $\left(\mathbf{R}^{2}\right)$}

Nilai koefisien determinasi atau $R$ Square adalah 0,833 atau 83,3\%. Hal ini dapat diartikan bahwa terdapat sebesar $83,3 \%$ variasi intensi turnover dijelaskan oleh varuasi dari variabel kepuasan kerja, komitmen organisasional dan motivasi kerja, 
sedangkan sebesar $16,7 \%$ dijelaskan oleh variabel lain yang tidak diteliti dalam penelitian ini.

\section{Matriks Korelasi Antar Dimensi}

Hubungan antar dimensi variabel-variabel penelitian ditunjukkan oleh matriks korelasi antar dimensi.

1. Variabel kepuasan kerja, dimensi yang paling kuat hubungannya adalah teman sekerja terhadap intention to quit karena memiliki nilai koefisien sebesar 0,947. Dimensi yang menunjukkan nilai negatif menyatakan bahwa jika dimensi tersebut dilakukan maka akan menyebabkan menurunnya intensi turnover.

2. Variabel komitmen organisasional, dimensi yang paling kuat hubungannya adalah komitmen berkelanjutan terhadap intention to quit karena memiliki nilai koefisien sebesar 0,936. Dimensi yang menunjukkan nilai negatif menyatakan bahwa jika dimensi tersebut dilakukan maka akan menyebabkan menurunnya intensi turnover.

3. Variabel Motivasi kerja, dimensi yang paling kuat hubungannya adalah kebutuhan afiliasi terhadap intention to quit karena memiliki nilai koefisien sebesar 0,930. Dimensi yang menunjukkan nilai negatif menyatakan bahwa jika dimensi tersebut dilakukan maka akan menyebabkan menurunnya intensi turnover.

\section{Kesimpulan}

1. Kepuasan kerja berpengaruh signifikan terhadap intensi turnover

2. Komitmen organisasional berpengaruh signifikan terhadap intensi turnover

3. Motivasi kerja tidak berpengaruh signifikan terhadap intensi turnover.

\section{Saran}

1. Pengawasan atasan terhadap karyawannya menjadi hal yang perlu diperhatikan oleh perusahaan. Hal tersebut akan berdampak pada tingkat kepuasan kerja karyawan kepada atasannya. Sistem pengawasan yang baik antara atasan dengan karyawannya akan meningkatkan hubungan erat satu sama lain yang berdampak pada kepuasan kerja karyawan. 
2. Perusahaan harus melibatkan rasa emosional para karyawannya agar komitmen yang ada dalam dirinya dapat meningkat. Meningkatnya komitmen afektif karyawan dapat menurunkan intensi karyawan untuk keluar atau mencari pekerjaan lain.

3. Perusahaan harus lebih meningkatkan kepuasan kerja pada karyawan, seperti hubungan antara atasan dan teman kerja maupun meningkatkan gaji/upah. Hal ini diharapkan dapat menekan intensi turnover pada periode berikutnya.

\section{REFERENSI}

Firdaus, Ahmad. 2017. Faktor-Faktor yang Mempengaruhi Turnover Intention (Studi Pada Karyawan Jasa Multi Finance di Kota Jambi). Jurnal of Economics and Business. Vol 1 No. 1.

Luthans, Fred. 2011. Perilaku Organisasi, (Alih Bahasa V.A Yuwono, dkk),Edisi Bahasa Indonesia, Yogyakarta: ANDI.

Mathis, L. Robert and Jackson, H. John. (2001). Manajemen Sumber Daya Manusia. Jakarta : Buku kedua

------, (2004). Human Resource Management, 10 ${ }^{\text {th }}$ Edition. Thomson Custom Publishing.

Martoyo, S. (1994). Manajemen Sumber Daya Manusia, Edisi ke-2. Yogyakarta: BPFE.

Mobley, W., Horner, S., and Hollingsworth, A. (1978). An Evaluation of Precursers of Hospital Employee Turnover. Journal of Apllied Psychology.

Nurandini, Arina. (2014). Analisis Pengaruh Komitmen Organisasi Terhadap Kinerja Karyawan (Studi Pada Pegawai Perum PERUMNAS Jakarta). Jurnal Studi Managemen \& Organisasi 11.

Putrianti, Arin Dewi; Hamid, Djamhur dan M. Djudi Mukzam. (2014). Pengaruh Kompensasi dan Motivasi Kerja Terhadap Turnover Intention (Studi Pada Karyawan PT. TIKI Jalur Nugraha Ekakurir Pusat Malang). Jurnal Administrasi Bisnis (JAB), Volume 12 No.2

Robbins, S. (2008). Perilaku Organisasi, $12^{\text {nd }}$ Edition. Prentice Hall.

Soeghandi, Vannecia Marchelle., Sutanto, Eddy M. dan Roy Setiawan. (2013). Pengaruh Kepuasan Kerja dan Loyalitas Terhadap Organizational Citizenship Behaviour pada Karyawan PT. Surya Timur Sakti Jatim. AGORA, Vol.1 No.1.

Wahyuni, Ana Sri; Zaika, Yulvi dan Ruslin Anwar. (2014). Analisis Faktor-Faktor yang Mempengaruhi Turnover Intention (Keinginan Berpindah) Karyawan Pada Perusahaan Jasa Konstruksi. Jurnal Rekayasa Sipil, Volume 8, No.2. 